\title{
Second-generation ethanol from pineapple leaf fibers
}

\section{Claudemir Natalino da Silva, Giovana Roberta Francisco Bronzato, Ivana Cesarino \& Alcides Lopes Leão}

To cite this article: Claudemir Natalino da Silva, Giovana Roberta Francisco Bronzato, Ivana Cesarino \& Alcides Lopes Leão (2018): Second-generation ethanol from pineapple leaf fibers, Journal of Natural Fibers, DOI: 10.1080/15440478.2018.1469453

To link to this article: https://doi.org/10.1080/15440478.2018.1469453

\section{Published online: 02 May 2018.}

Submit your article to this journal $₫$

山ll Article views: 33

View Crossmark data \lceil

Citing articles: 1 View citing articles 5 


\title{
Second-generation ethanol from pineapple leaf fibers
}

\author{
Claudemir Natalino da Silva, Giovana Roberta Francisco Bronzato, Ivana Cesarino, \\ and Alcides Lopes Leão
}

School of Agriculture, São Paulo State University (UNESP), Botucatu, Brazil

\begin{abstract}
The use of different lignocellulosic residues for the production of cellulosic ethanol is an alternative for the expanding demand of this fuel without increasing the planting area of traditional carbohydrate crops. One of the proposed alternatives is the use of pineapple leaf fibers (PALF) residues, which is a material rich in cellulose that can be used as raw material for second-generation $(2 \mathrm{G})$ ethanol production. In this study, the PALF was pretreated using an alkaline medium combined with a steam explosion and the $2 \mathrm{G}$ ethanol produSction was analyzed by two-way processes to enzymatic hydrolysis using separated hydrolysis and fermentation (SHF) or simultaneous saccharification and fermentation (SSF). Using SHF, the alcoholic fermentation process with addition of molasses provided good fermentability and can handle larger loads of carbohydrate in shorter fermentation time. The SSF was a better method for $2 \mathrm{G}$ ethanol production from PALF yielding $96.12 \%$. Therefore, PALF is presented as good raw material for production of $2 \mathrm{G}$ ethanol, with all the environmental and social advantages of such approach.

摘要

使用不同木质纤维素残余物生产纤维素乙醇是一种替代燃料的需求, 而 不增加传统碳水化合物作物的种植面积。提出的替代方案之一是菠萝叶 纤维 (PALF) 残留物的使用, 这是一种富含纤维素的材料, 可以用作第 二代 (2G) 乙醇生产的原料。本研究采用碱性介质和蒸汽爆破技术对菠 萝叶纤维进行预处理, 采用双向水解、发酵 (SHF) 或同步糖化发酵两种 工艺对2G乙醇生产进行酶解分析。N(SSF)。采用分离的水解和发酵, 添加糖蜜酒精发酵过程提供了良好的发酵性，并能在较短的发酵时间内 处理较大的碳水化合物负荷。同时糖化发酵是菠萝叶纤维生产 $2 \mathrm{~g}$ 乙醇的 较好方法, $96.12 \%$ 的菠萝叶纤维是生产第二代乙醇的良好原料, 具有良 好的环境和社会效益。ES的这种方法。
\end{abstract}

\section{KEYWORDS}

Pineapple; secondgeneration ethanol; lignocellulosic residues; biofuel; separated hydrolysis and fermentation; simultaneous saccharification and fermentation

\section{关键词}

菠萝; 第二代乙醇; 木质纤 维素残留物; 生物燃料; 分 离水解发酵; 同步糖化发酵

\section{Introduction}

One of the biggest global challenges is the search for biofuels that will replace oil, a source of fossil fuel non-renewable and potential polluting. Energy security and climate changes require a large-scale replacement of petroleum-based fuels (Kohlhepp 2010). Currently, ethanol is the most important renewable fuel and its use in large-scale contributes directly to reducing the environmental impact of indiscriminate use of fossil fuels (Taherzadeh, and Karimi 2008). The addition of ethanol to gasoline improves fuel economy and reduces emissions of $\mathrm{CO}, \mathrm{HC}$, and $\mathrm{NO}_{\mathrm{x}}$ from internal combustion engines. However, the incomplete combustion of ethanol produces high concentrations of aldehydes. These compounds are highly reactive and participate in complex chemical reactions in the 
atmosphere. The emissions of aldehydes are higher for ethanol fuel due to the presence of the hydroxyl functional group, which are not present in the traditional gasoline.

For the Europe, the production of ethanol from lignocellulosic biomass, or second-generation $(2 \mathrm{G})$ ethanol, is strategic to reach the mandatory targets - reduce in this decade $10 \%$ of the use of fossil fuels for transportation. The $2 \mathrm{G}$ ethanol is a sustainable technology that avoids competition with food agriculture, allows the use of agriculture and forestry residues and reduce environmental risks, which are associated to first-generation biofuels, as ethanol from sugar cane or corn and the diesel oil. Moreover, 2G ethanol pathway has several promising applications in the biorefinery concept as the use of lignin processing for resin and chemicals production (Conata et al. 2014).

The bio-ethanol production from agro-residues involve five processes: biomass grinding, pretreatment, enzymatic hydrolysis, fermentation, and distillation. For the ethanol produced from lignocellulosic materials must be available sugars that are grouped in the polymers forming the wall structure of the plant (Bom, Ferrara, and Corvo 2008). The lignocellulosic materials are strongly recalcitrant because of the strong link between hemicellulose, cellulose, and lignin; therefore, different processes must be use. These processes have several challenges and limitations such as biomass transport and handling, and efficient pretreatment process for removing the lignin from the lignocellulosic agro-residues. The pretreatment processes of lignocellulosic materials can be thermal, chemical, physical, biological, or a combination thereof, which depends on the required degree of separation and the proposed end. Pretreatment process can increase the concentrations of fermentable sugars after enzymatic hydrolysis, thereby improving the efficiency of the whole process. The remaining steps of fermentation and distillation follow the same processes of conventional ethanol production (Gupta, and Prakash 2015).

One of the proposed alternatives for the $2 \mathrm{G}$ ethanol production is the use of pineapple leaves as post-harvest waste, since this material has a significant amount of fiber, which is nowadays discarded. The exploitation of natural resources is taking fundamental importance for the improvement and possible solution of social-economical problems, especially in disadvantaged regions, such as the Brazilian Northeast (Leao et al. 2015).

The pineapple or "ananas" names used both as the fruit to the plant belongs to the family Bromeliacea and genus Ananas mill. This genus is widely distributed in tropical regions through the species Ananas comosus (L.) which covers all cultivate planted pineapple. It is originating in the Americas and expanded in Asia and Africa. Brazil, Thailand, Philippines, Costa Rica, and Indonesia are the main pineapple producers in the world (FAOSTAT 2016).

Pineapple waste, is the by-product of the canned pineapple, is a material rich in cellulose, hemicelluloses, sugar, and other carbohydrates. These wastes consist of residual pulp, peels, and skin. High amount of reducing sugars in dried pineapple peel prompted us to attempt to utilize it as a raw material for biofuel production. Also, develop of cheap medium (Choonut, Saejong, and Sangkharak 2014) that would be used to convert invaluable product to valuable products as well as to clean the environment from wastes and reduce the pollution (Hossain, and Fazliny 2010). After the fibers extraction and process, the resulting mucilage can also generate numerous products in various areas, make them suitable for many industrial applications, including pharmaceuticals and animal feed, manufacture of yarn, woven fabrics, woven knitted, non-woven mats and handmade products, textile materials and reinforcing composites (Leao et al. 2015; Sapuan, Mohamed, and Ishak 2011).

The pineapple leaf fibers (PALF) can be a viable alternative to supply the deficiency of long fibers in Brazil and in many other tropical countries. Among the various types of natural fibers, PALF exhibits excellent mechanical properties. The superior mechanical properties of the PALF are associated with its high cellulose content and low micro-fibril angle (Leao et al. 2015).

Considering that which has been described above, the present manuscript deals the ethanol production and what the better way to obtaining $2 \mathrm{G}$ ethanol from PALFs. 


\section{Material and methods}

\section{Material}

The pineapple leaves used in this study were collected from a private plantation in the Pederneiras city, São Paulo state. The material, about $1.2 \mathrm{~kg}$, was washed to remove dirt, chopped, dried at room temperature, and pretreated. Commercial enzyme Accellerase DuPont ${ }^{\circledR}$ cellulase was used for the hydrolysis and to fermentation were used commercial yeast Saccharomyces cerevisiae (SA-1).

\section{Chemical characterization of pineapple lignocellulosic materials}

The characterization of biomass followed the methodology described by the National Renewable Energy Laboratory of the United States. The method determines the percentage of carbohydrate (cellulose and hemicellulose) and lignin, both in the material fresh and in pretreated. The total amount of solid material was determined so that the results were reported based on the quantity of dry biomass. It was used acid hydrolysis with two explosion in order to hydrolyze the polysaccharides to monosaccharides biomass to more easily quantifiable portions. Lignin was fractionated soluble material and insoluble material, both in acid.

The acid-insoluble material includes gray and proteins, which were calculated by gravimetric analysis. The acid soluble lignin could be quantified by UV spectroscopy in the visible region. During hydrolysis, polymeric carbohydrates were hydrolyzed in the monomeric forms, which are soluble in the liquid hydrolysis. These were measured by high performance liquid chromatography (HPLC).

\section{Structural carbohydrates}

Initially the samples were prepared with particle size of 20 mesh in mill, weighed $0.3 \mathrm{~g}$ of the material raw or pretreated in special tube with lid and added $3.0 \mathrm{~mL}$ of $\mathrm{H}_{2} \mathrm{SO}_{4} 72 \% \mathrm{v} / \mathrm{v}$ under manual shaking with bat individual glass for each sample, into warm bath of $40^{\circ} \mathrm{C}$ for $60 \mathrm{~min}$. The solution was diluted to concentration around $4 \%$.

The material was kept to autoclave for $60 \mathrm{~min}$ at $121^{\circ} \mathrm{C}$ and $1.2 \mathrm{kgf} / \mathrm{cm}^{2}$. After completion of the autoclave cycle, the tube was slowly cool to room temperature before opening. The filtered solution in vacuum hydrolyzed by autoclaving porous crucible weighed initially, the filtrate collected in a $100 \mathrm{~mL}$ volumetric flask. The hydrolyzed portion was prepared for analysis by HPLC and UV-vis spectroscopy for the analysis of structural carbohydrates and lignin in biomass soluble acid respectively.

\section{Determination of soluble and insoluble lignin}

The insoluble lignin in acidic medium was determined gravimetrically after filtration of the insoluble residue in an acidic medium in a pre-measured Gooch crucible, at $575^{\circ} \mathrm{C}$ for $6 \mathrm{~h}$, and dried at $105^{\circ} \mathrm{C}$ until constant weight. Lignin was determined in acid-insoluble by mass difference. Lignin soluble in acid was quantified by UV-vis spectroscopy in the region between 210 and $280 \mathrm{~nm}$.

\section{Moisture and ash}

For the moisture, approximately $2.0 \mathrm{~g}$ of biomass was weighed in a porcelain crucible, pre-calibrated. The material was kept in an oven at $105^{\circ} \mathrm{C}$ under vacuum until constant weight and stored in desiccators. Then, the mass was measured again. The dried sample was subjected to heating at $575^{\circ} \mathrm{C}$ under $24 \mathrm{~h}$ and the ash contents were weighed.

\section{Pretreatment methods}

The delignification process was carried out in an autoclave type electronics reactor (Santos, and Gouveia 2009). Approximately $300 \mathrm{~g}$ of biomass was placed in $1.0 \mathrm{~L}$ of sodium hydroxide solution $2.0 \mathrm{~mol} \mathrm{~L}^{-1}$ and kept in an autoclave under pressure of 2 bars, $120^{\circ} \mathrm{C}$ for $30 \mathrm{~min}$ and then, they were depressurized. This 
process was repeated twice for each material and evaluated conditions for each step. After delignification, the pretreated material was separated from the liquor by filtration. The material was washed with heated distilled water to remove the lignin further impregnated. The material was dried at $60^{\circ} \mathrm{C}$.

\section{Separated hydrolysis and fermentation (SHF)}

\section{Enzymatic hydrolysis}

Tests of enzymatic hydrolysis of pretreated biomass pineapple were performed in an appropriate glass vials $2.0 \mathrm{~L}$ mechanically stirred and heated bath, $83 \mathrm{~g}$ of material with $10 \%$ humidity in $1.5 \mathrm{~L}$ of water resulting in $5 \%$ solids in the reactor, the $\mathrm{pH}$ adjusted with sodium citrate buffer $(\mathrm{pH} 4.8)$ and added to $18.5 \mathrm{~mL}$ of the cellulase enzyme.

The bottles in all enzymatic hydrolysis were kept in a warm bath at $50^{\circ} \mathrm{C}$ for $48 \mathrm{~h}$. Aliquots were collected at time $0,6,12,24,36$, and $48 \mathrm{~h}$ to monitor the formation of the desired products curve. All samples were centrifuged for $10 \mathrm{~min}$ at $10,000 \mathrm{rpm}$, and the supernatants filtered through a membrane of $0.45 \mu \mathrm{m}$ and used for quantification of carbohydrates, glycerol, ethanol, and organic acids by HPLC.

\section{Alcoholic fermentation}

Fermentation was done using the hydrolyzed liquor after filtration from the hydrolysis process. The fermentation trials were performed in a $1.0 \mathrm{~L}$ erlenmeyer flask with $0.5 \mathrm{~L}$ volume of work added $2 \%$ of $S$. cerevisiae (SA-1). Fermentation occurred in the anaerobic process temperature of $32^{\circ} \mathrm{C}, \mathrm{pH} 4.8$ in a magnetic stir plate for $26 \mathrm{~h}$. The glucose consumption and ethanol formation were measured by HPLC during the fermentation process.

Another fermentation of the hydrolyzed broth was made with addition of the molasses to increase the carbohydrate load. It was used $0.5 \mathrm{~L}$ of the hydrolyzed broth and $0.25 \mathrm{~L}$ of the molasses and the process conditions with shaking at $120 \mathrm{rpm}, 32^{\circ} \mathrm{C}$, and $8 \mathrm{~h}$ with $2 \%$ procedure of $S$. cerevisiae with pH 4.8 .

After completion of the fermentation, the fermented wine is centrifuged for about $5 \mathrm{~min}$ at $3600 \mathrm{rpm}$. A sample of wine yeast is collected and stored in a freezer for determination of residual carbohydrates, ethanol, glycerol, and acetic acid by HPLC.

\section{Simultaneous saccharification and fermentation (SSF)}

The pretreated pineapple fibers were subjected to SSF process, using a $2.0 \mathrm{~L}$ volume glass bottle, mechanical stirrer and a heating bath. An amount of $83 \mathrm{~g}$ of fibers with moisture content of $10 \%$ by volume with water resulting in $1.5 \mathrm{~L} 5 \%$ solids was placed in the reactor. The $\mathrm{pH}$ was adjusted with the sodium citrate buffer $(\mathrm{pH} 4.8)$ and there were added $18.5 \mathrm{~mL}$ of the cellulase enzyme. The material was kept to bath at $50^{\circ} \mathrm{C}$ for $6 \mathrm{~h}$, pre-saccharification. After this period, the temperature was reduced to $38^{\circ} \mathrm{C}$ and added $2.0 \mathrm{~g}$ of $30 \%$ or commercial yeast, starting to SSF process itself occurred in a total of $48 \mathrm{~h}$ time. Aliquots withdrawn at time $0,6,12 ; 24 ; 36$ and $48 \mathrm{~h}$ to monitor the formation of the desired products curve. All samples were centrifuged for $10 \mathrm{~min}$ at 10,000 rpm, and the supernatants were filtered through a membrane of $0.45 \mu \mathrm{m}$. The quantification of carbohydrates, glycerol, ethanol, and organic acids had made by HPLC.

\section{Results and discussion}

\section{Chemical characterization of pineapple lignocellulosic materials}

The effect of pretreatment and delignification by vapor pressure in alkaline medium, affected the structural organization of the lignocellulosic material, solubilizing hemicellulose and acids from the break of the weakest bonds (Ramos 2003). 
Sodium hydroxide caused the swelling by increasing the internal surface area of the pulp and reducing the degree of polymerization and crystallization, which caused the break of the lignin and carbohydrate structure, solubilizing lignin (Yu, Lou, and Wu 2008).

The raw and pretreated biomasses were analyzed by comparing the efficiency of delignification process at each step and it is also noted that the pineapple biomass do not have a lot lignin as in other recalcitrant plants, thus the delignification process need not be very severe.

Table 1 shows the chemical characterization of in nature biomass and pretreated in the two explosion. These analyses show that hemicellulose and lignin were removed. It increased the cellulose content in the solid fraction, while the acid-insoluble lignin in the biomass in fresh $51 \%$ decreases relative to the delignified biomass. Figure 1 shows the effectiveness of pretreatment on removal lignin, acetic acid and an increase in the percentage of cellulose.

\section{Glucose-cellulose conversion in the process of enzymatic hydrolysis}

The pretreatment of biomass using S. cerevisiae microorganism solubilized most of the hemicelluloses because it does not ferment pentose. The sugars from hemicellulose after the pretreatment can be converted to ethanol by fermentation using other microorganisms that can convert these.

This paper describes two enzymatic hydrolysis procgesses: the first process used was the enzymatic hydrolysis with subsequently fermentation called SHF and the second process was SSF. In the SHF process, the cellulose was hydrolyzed to glucose by cellulase enzymes in $48 \mathrm{~h}$. The amount of glucose obtained at the end of the process was $31.02 \mathrm{~g} \mathrm{~L}^{-1}$ with a yield of $70 \%$ conversion. The yield

Table 1. Chemical characterization of in nature and pretreated biomass in the two explosion.

\begin{tabular}{|c|c|c|c|}
\hline \multicolumn{4}{|c|}{ Chemical composition of lignocellulosic PALF in \% } \\
\hline & In nature & 1st explosion & 2nd explosion \\
\hline Cellulose & 24.65 & 32.87 & 56.89 \\
\hline Xylose & 25.23 & 18.36 & 15.95 \\
\hline Arabinose & 0.82 & 0.81 & 0.00 \\
\hline Acetic acid & 2.54 & 0.00 & 0.00 \\
\hline Sol. Lignin & 2.00 & 1.35 & 2.09 \\
\hline Insol. Lignin & 20.67 & 13.22 & 10.07 \\
\hline Ash & 17.30 & 18.78 & 9.51 \\
\hline
\end{tabular}

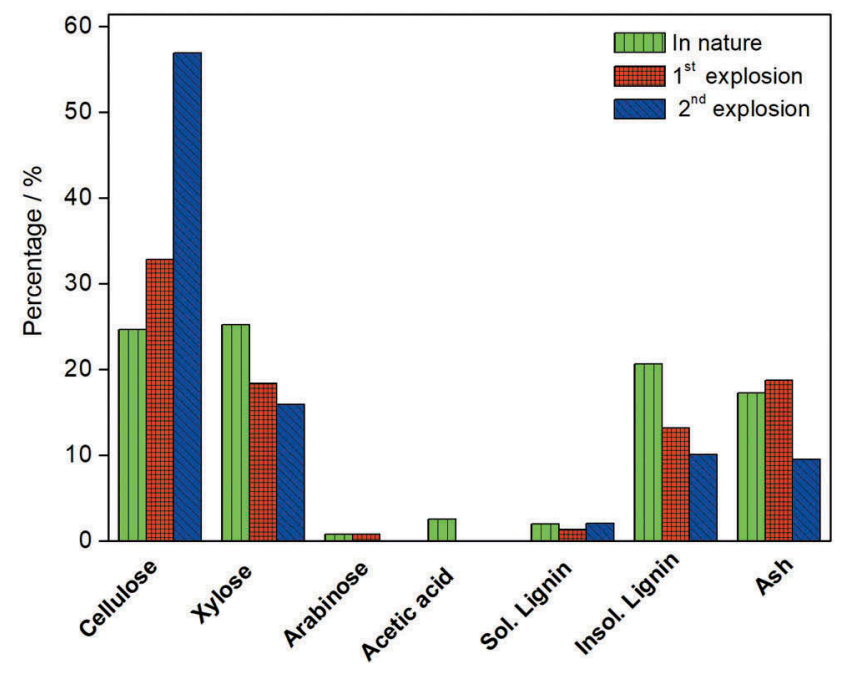

Figure 1. Chemical composition of the PALF. 
can be considered good, however the amount of glucose obtained was very low, because the solid loading was $10 \%$ inasmuch as the equipment used do not withstand a higher solids loading. The disadvantage of working at low solids concentration is the low concentration of free sugar for fermentation and consequently low ethanol producted thereby increased energy expenditure for recovery in the distillation of ethanol.

Table 2 shows the evolution of the enzymatic process where the carbohydrates are formed over time. Half conversion occurs within the first $4 \mathrm{~h}$ of hydrolysis and at the end of the process showed a $70.13 \%$ conversion of cellulose to glucose in $48 \mathrm{~h}$ the amount of glucose was $31.02 \mathrm{mg} \mathrm{mL}$.

\section{Comparing SHF - SSF}

The main advantage of SHF method is that the hydrolysis and fermentation may be conducted under optimal conditions. The optimum temperature for cellulase is $45-50^{\circ} \mathrm{C}$ and optimum temperature for fermentation is between 30 and $37^{\circ} \mathrm{C}$ (Olsson et al. 2006). The main disadvantage is the inhibition of the cellulosic complex sugars released in the hydrolysis mainly cellobiose and glucose to accumulate in the medium, giving an incomplete hydrolysis of cellulose and decreasing yield. Another disadvantage is the possible contamination because the time involved in the hydrolysis step is too long and the carbohydrate solution becomes a source available for undesired microorganisms. Furthermore, the enzymes themselves can be a potential source of contamination (Taherzadeh, and Karimi 2008).

In the SSF process there is simultaneous hydrolysis and fermentation. A pre-hydrolysis step with a time of $8 \mathrm{~h}$ was done to release glucose to enable fermentation with yeast, S. cerevisiae. This process accelerates the fermentation, adding the microorganism to ferment adjusting means. Figure 2 shows

Table 2. Results of PALF enzymatic hydrolysis.

\begin{tabular}{lcccc}
\hline Sample $(\mathrm{h})$ & Glucose $(\mathrm{mg} / \mathrm{mL})$ & Cellobiose $(\mathrm{mg} / \mathrm{mL})$ & $\begin{array}{c}\text { Xylose } \\
(\mathrm{mg} / \mathrm{mL})\end{array}$ & Arabinose $(\mathrm{mg} / \mathrm{mL})$ \\
\hline 4 & 12.00 & 0.77 & 1.07 & 0.02 \\
9 & 17.37 & 0.78 & 1.92 & 0.02 \\
12 & 19.10 & 1.92 & 2.16 & 0.01 \\
24 & 29.56 & 3.70 & 4.08 & 0.02 \\
36 & 30.05 & 3.59 & 3.66 & 0.05 \\
48 & 31.02 & 3.99 & 4.17 & 0.05 \\
\hline
\end{tabular}

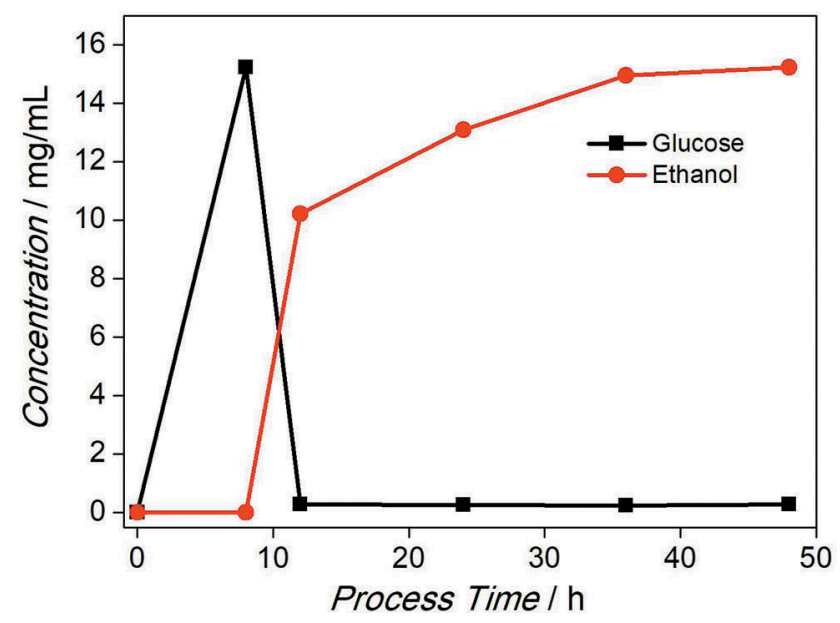

Figure 2. $2 \mathrm{G}$ ethanol production by SSF process. 
the glucose consumption after the addition of the microorganism in the middle where it can be seen that all the glucose generated in the pre-hydrolysis step was consumed rapidly, therefore after $12 \mathrm{~h}$ the process releases all glucose was being consumed.

In this process, it is expected a disadvantage in enzyme kinetics due to the need to adapt the process within the temperature range tolerable to the fermenter microorganism $\left(38^{\circ} \mathrm{C}\right)$, out of range temperature optimum of the enzymes $\left(50^{\circ} \mathrm{C}\right)$ specified by the manufacturer. However, was obtained a higher yield in ethanol production at the end of $15.24 \mathrm{mg} \mathrm{mL}^{-1}$ process, yield $96.12 \%$ to compare with the SHF process, as can observed in Table 3.

According to Öhgren et al. (2007), in the SSF process is the reduction of inhibition of cellulase by its hydrolysis products, since the carbohydrate does not accumulate in the medium. These synergistic groups of enzymes work better when the amount of glucose released in the process is simultaneously consumed. Also back cost and lower complexity of the process compared to SHF because it reduces the number of reactors; minimize the risk of contamination due to low concentrations of sugar free medium; hydrolysis and higher yields, as the balance of the enzymatic reactions are shifted toward more product formation (Vásquez et al. 2007).

\section{Alcoholic fermentation with addition of molasses}

In the process of fermentation of the hydrolyzed broth, Figure 3 shows that the glucose consumption occurred during the first $6 \mathrm{~h}$ of the process. This occurs because of the amount of glucose in the medium was very low $(31.02 \mathrm{mg} / \mathrm{mL})$, compared with a conventional process of fermentation that works in the range of $160 \mathrm{mg} / \mathrm{mL}$ of carbohydrate. This was the low solid load on the enzymatic hydrolysis process. Table 4 summarizes the glucose-ethanol conversion results.

Table 3. Conversion rates in the SSF process.

\begin{tabular}{lccccc}
\hline Time $(\mathrm{h})$ & Glucose $(\mathrm{mg} / \mathrm{mL})$ & Glycerol $(\mathrm{mg} / \mathrm{mL})$ & Acetic acid $(\mathrm{mg} / \mathrm{mL})$ & Ethanol $(\mathrm{mg} / \mathrm{mL})$ & Conversion rate $(\%)$ \\
\hline 8 & 15.24 & 0.00 & 0.53 & 0.00 & 0.00 \\
12 & 0.29 & 2.11 & 0.83 & 10.23 & 64.52 \\
24 & 0.27 & 2.62 & 0.84 & 13.09 & 82.56 \\
36 & 0.25 & 2.77 & 1.32 & 14.96 & 94.36 \\
48 & 0.29 & 2.75 & 2.72 & 15.24 & 96.12 \\
\hline
\end{tabular}

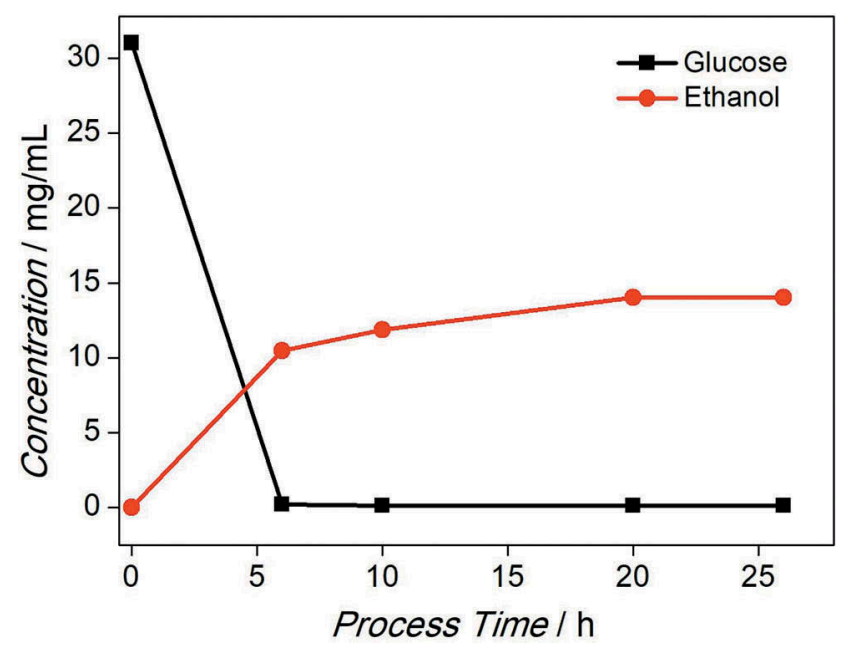

Figure 3. $2 \mathrm{G}$ ethanol production by separate hydrolysis and fermentation process. 
Table 4. Conversion rate in the process of fermentation of the hydrolyzed broth.

\begin{tabular}{lccccc}
\hline Time $(\mathrm{h})$ & Glucose $(\mathrm{mg} / \mathrm{mL})$ & Glycerol $(\mathrm{mg} / \mathrm{mL})$ & Acetic acid $(\mathrm{mg} / \mathrm{mL})$ & Ethanol $(\mathrm{mg} / \mathrm{mL})$ & Conversion rate $(\%)$ \\
\hline 0 & 31.02 & 0.00 & 0.00 & 0.00 & 0.00 \\
6 & 0.21 & 1.84 & 0.69 & 10.45 & 65.91 \\
10 & 0.13 & 2.08 & 0.95 & 11.85 & 74.74 \\
20 & 0.13 & 2.26 & 1.09 & 14.01 & 88.36 \\
26 & 0.11 & 2.42 & 1.30 & 14.02 & 88.43 \\
\hline
\end{tabular}

Table 5. Fermentation of the broth with addition of the hydrolyzed molasses.

\begin{tabular}{lccccccc}
\hline Time $(\mathrm{h})$ & $\begin{array}{c}\text { Sucrose } \\
(\mathrm{mg} / \mathrm{mL})\end{array}$ & $\begin{array}{c}\text { Glucose } \\
(\mathrm{mg} / \mathrm{mL})\end{array}$ & $\begin{array}{c}\text { Fructose } \\
(\mathrm{mg} / \mathrm{mL})\end{array}$ & $\begin{array}{c}\text { Glycerol } \\
(\mathrm{mg} / \mathrm{mL})\end{array}$ & $\begin{array}{c}\text { Acetic acid } \\
(\mathrm{mg} / \mathrm{mL})\end{array}$ & $\begin{array}{c}\text { Ethanol } \\
(\mathrm{mg} / \mathrm{mL})\end{array}$ & $\begin{array}{c}\text { Formic acid } \\
(\mathrm{mg} / \mathrm{mL})\end{array}$ \\
\hline 0 & 49.99 & 52.29 & 40.96 & 0.18 & 0.77 & 3.27 & 0.44 \\
8 & 2.51 & 0.12 & 2.23 & 6.9 & 1.23 & 72.11 & - \\
\hline
\end{tabular}

As the fermentation of the hydrolyzed broth occurred in the first hours, another fermentation was carried out increasing the carbohydrate load, since in the first hydrolysis only $31.02 \mathrm{~g} / \mathrm{L}$ of glucose was obtained, due the low solid load (10\%). Another fermentation process was performed adding the molasses from sugar production, to compare if the yeast used would ferment a larger amount of sugar in less time. Results were compared and are summarized in Table 5.

As shown in Table 5, the fermentation process time of $8 \mathrm{~h}$ could ferment nearly all sugars available in the sample. Thus, it is observed that the hydrolyzed broth of pineapple pulp has the same fermentation aspects of a first generation broth. It is possible to work more carbohydrate load and shorter fermentation, bringing more efficiency and reducing costs process.

\section{Conclusion}

The production of $2 \mathrm{G}$ ethanol from lignocellulosic residues pineapple is an alternative to enhance the pineapple chain production and also add value to the agricultural waste. The fibers found in the agricultural waste have about $25 \%$ cellulose, $25 \%$ hemicellulose, and $22 \%$ lignin. The pineapple fibers do not have a very strong recalcitrance, thus, did not require pretreatment as severe as in other types of fibers.

Enzymatic hydrolysis of cellulose revealed a good conversion of glucose, however, due to work with low solid load (10\%) concentration was $31.02 \mathrm{mg} / \mathrm{mL}$ glucose at the end of the process.

The SSF conversion showed an advantage because the enzymes act better, thereby, increasing efficiency and also use less reactor production time, with yield of $96.12 \%$.

For the fermentation, it was observed that the hydrolyzed broth showed good fermentability and can handle larger loads of carbohydrate in shorter fermentation time.

Thus, the PALFs can be considered a good raw material for production of $2 \mathrm{G}$ ethanol.

\section{Acknowledgments}

The authors would like to acknowledge the financial support of FAPESP (2015/21395-9), CNPq and CAPES.

\section{Funding}

This work was supported by the Fundação de Amparo à Pesquisa do Estado de São Paulo [2015/21395-9];

\section{References}

Bom, E. P. S., M. A. Ferrara, and M. L. Corvo. 2008. Enzima em biotecnologia: Produção, aplicação e mercado. Rio de Janeiro: Ed. Interciência. 
Choonut, A., M. Saejong, and K. Sangkharak. 2014. The production of ethanol and hydrogen from pineapple peel by Saccharomyces cerevisiae and Enterobacter aerogenes. Energy Procedia 52:242-49. doi:10.1016/j.egypro.2014.07.075.

Conata, F., G. Cavalaglio, M. Gelosia, A. Nicolini, V. Coccia, and A. Petrozzi. 2014. Production of bioethanol in a second generation prototype from pine wood chips. Energy Procedia 45:41-51.

FAOSTAT. 2016. United Nations Food and Agriculture Organization of the United Nations. http://www.fao.org/ statistics/en.

Gupta, A., and J. Prakash. 2015. Sustainable bio-ethanol production from agro-residues : A review. Renewable \& Sustainable Energy Reviews 41:550-67. doi:10.1016/j.rser.2014.08.032.

Hossain, A., and A. R. Fazliny. 2010. Creation of alternative energy by bio-ethanol production from pineapple waste and the usage of its properties for engine. African Journal of Microbiology Research 4 (9):813-19.

Kohlhepp, G. 2010. Análise da situação da produção de etanol e biodiesel no Brasil. Estudos Avançados 24 (68):223-53. doi:10.1590/S0103-40142010000100017.

Leao, A. L., B. M. Cherian, S. Narine, S. F. Souza, M. Sain, and S. Thomas. 2015. The use of pineapple leaf fibers (PALFs) as reinforcements in composites. In Biofiber reinforcements in composites. eds. O. Faruk \& M. Sain, Cambridge, UK: Woodhead Publishing Ltd.

Öhgren, K., R. Bura, G. Lesnicki, J. Saddler, and G. Zacchi. 2007. A comparison between simultaneous saccharification and fermentation and separate hydrolysis and fermentation using steam-pretreated corn stover. Process Biochemistry 42 (5):834-39. doi:10.1016/j.procbio.2007.02.003.

Olsson, L., H. R. Soerensen, B. P. Dam, H. Christensen, K. M. Krogh, and A. S. Meyer. 2006. Separate and simultaneous enzymatic hydrolysis and fermentation of wheat hemicellulose with recombinant xylose utilizing Saccharomyces cerevisiae. Applied Biochemistry and Biotechnology 129-132:117-29. doi:10.1385/ABAB:129:1:117.

Ramos, L. P. 2003. The chemistry involved in the steam treatment of lignocellulosic materials. Química Nova 26 (6):863-71. doi:10.1590/S0100-40422003000600015.

Santos, E., and J. R. A. Gouveia. 2009. Produção de bioetanol de bagaço de cana-de-açúcar. Revista Brasileira De Produtos Agroindustriais 11 (1):33-27. doi:10.15871/1517-8595/rbpa.v11n1p27-33.

Sapuan S.M., Mohamed A.R., Siregar J.P., and Ishak M.R. 2011. Pineapple Leaf Fibers and PALF-Reinforced Polymer Composites. In Cellulose Fibers: Bio-and Nano-Polymer Composites, eds. S. Kalia, B. Kaith, and I. Kaur. Berlin, Heidelberg: Springer.

Taherzadeh, M. J., and K. Karimi. 2008. Pretreatment of lignocellulosic wastes to improve ethanol and biogas production: A review. International Journal of Molecular Sciences 9 (9):1621-51. doi:10.3390/ijms9091621.

Vasquez, N., M. P. Silva, J. M. C. Souza Jr., and M. B. Pereira Jr. 2007. Enzymatic hydrolysis optimization to ethanol production by saccharification and fermentation. Applied Biochemistry and Biotechnology 137-140:141-53. doi:10.1007/s12010-007-9046-2.

Yu, Y., X. Lou, and H. Wu. 2008. Some recent advances in hydrolysis of biomass in hot-compressed water and its comparisons with other hydrolysis methods. Energy and Fuels 22 (1):46-60. doi:10.1021/ef700292p. 